\title{
Long-term survival of stage T4N0-1 and single station IIIA-N2 NSCLC patients treated with definitive chemo- radiotherapy using individualised isotoxic accelerated radiotherapy (INDAR)
}

Citation for published version (APA):

Reymen, B., van Baardwijk, A., Wanders, R., Borger, J., Dingemans, A-M. C., Bootsma, G., Pitz, C., Lunde, R., Geraedts, W., Lambin, P., \& De Ruysscher, D. (2014). Long-term survival of stage T4N0-1 and single station IIIA-N2 NSCLC patients treated with definitive chemo-radiotherapy using individualised isotoxic accelerated radiotherapy (INDAR). Radiotherapy and Oncology, 110(3), 482-487. https://doi.org/10.1016/j.radonc.2013.12.005

Document status and date:

Published: 01/03/2014

DOI:

10.1016/j.radonc.2013.12.005

Document Version:

Publisher's PDF, also known as Version of record

\section{Document license:}

Taverne

\section{Please check the document version of this publication:}

- A submitted manuscript is the version of the article upon submission and before peer-review. There can be important differences between the submitted version and the official published version of record. People interested in the research are advised to contact the author for the final version of the publication, or visit the $\mathrm{DOI}$ to the publisher's website.

- The final author version and the galley proof are versions of the publication after peer review.

- The final published version features the final layout of the paper including the volume, issue and page numbers.

Link to publication

\footnotetext{
General rights rights.

- You may freely distribute the URL identifying the publication in the public portal. please follow below link for the End User Agreement:

www.umlib.nl/taverne-license

Take down policy

If you believe that this document breaches copyright please contact us at:

repository@maastrichtuniversity.nl

providing details and we will investigate your claim.
}

Copyright and moral rights for the publications made accessible in the public portal are retained by the authors and/or other copyright owners and it is a condition of accessing publications that users recognise and abide by the legal requirements associated with these

- Users may download and print one copy of any publication from the public portal for the purpose of private study or research.

- You may not further distribute the material or use it for any profit-making activity or commercial gain

If the publication is distributed under the terms of Article $25 \mathrm{fa}$ of the Dutch Copyright Act, indicated by the "Taverne" license above,

Download date: 26 Apr. 2023 
Chemoradiotheraphy of lung cancer

\title{
Long-term survival of stage T4N0-1 and single station IIIA-N2 NSCLC patients treated with definitive chemo-radiotherapy using individualised isotoxic accelerated radiotherapy (INDAR)
}

\author{
Bart Reymen $^{\mathrm{a}, *}$, Angela van Baardwijk ${ }^{\mathrm{a}}$, Rinus Wanders ${ }^{\mathrm{a}}$, Jacques Borger ${ }^{\mathrm{a}}$, Anne-Marie C. Dingemans ${ }^{\mathrm{b}}$, \\ Gerben Bootsma ${ }^{\mathrm{c}}$, Cordula Pitz ${ }^{\mathrm{d}}$, Ragnar Lunde ${ }^{\mathrm{e}}$, Wiel Geraedts ${ }^{\mathrm{f}}$, Philippe Lambin ${ }^{\mathrm{a}}$, Dirk De Ruysscher ${ }^{\mathrm{a}, \mathrm{g}}$

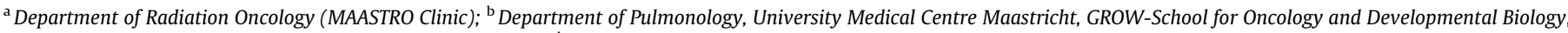

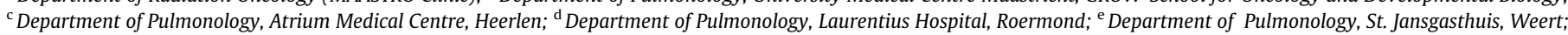 \\ ${ }^{\mathrm{f}}$ Department of Pulmonology, Orbis Medical Centre, Sittard, The Netherlands; ${ }^{\mathrm{g}}$ University Hospital Leuven/KU Leuven, Belgium
}

\section{A R T I C L E I N F O}

\section{Article history}

Received 16 July 2013

Received in revised form 10 December 2013

Accepted 18 December 2013

Available online 17 January 2014

\section{Keywords:}

Non-small cell lung cancer

Radiotherapy

Chemotherapy

Combined modality treatment

T4

\begin{abstract}
A B S T R A C T
Background: Non-small cell lung cancer (NSCLC) stage T4N0-1 or single nodal station IIIA-N2 are two stage III sub-groups for which the outcome of non-surgical therapy is not well known. We investigated the results of individualised isotoxic accelerated radiotherapy (INDAR) and chemotherapy in this setting. Methods: Analysis of NSCLC patients included in 2 prospective trials (NCT00573040 and NCT00572325) stage T4N0-1 or IIIA-N2 with 1 pathologic nodal station, treated with chemo-radiotherapy (CRT) using INDAR with concurrent or sequential platinum-based chemotherapy. Overall survival (OS) was updated and calculated from date of diagnosis (Kaplan-Meier). Toxicity was scored following CTCAEv3.0. To allow comparison with other articles the subgroups were also analysed separately for toxicity, progression free and overall survival.

Results: 83 patients (42 T4N0-1 and 41 IIIA-N2) were identified: the median radiotherapy dose was $65 \mathrm{~Gy}$. Thirty-seven percent of patients received sequential CRT and 63\% received concurrent CRT. At a median follow-up of 48 months the median OS for T4NO-1 patients was 34 months with $55 \%$ 2-year survival and 25\% 5-year survival. For stage IIIA-N2 at a median follow-up of 50 months the median OS was 26 months with 2 - and 5 -year survival rates of $53 \%$ and $24 \%$, respectively.

Conclusion: Chemo-radiation using INDAR yields promising survival results in patients with singlestation stage IIIA-N2 or T4N0-1 NSCLC.
\end{abstract}

(C) 2014 Elsevier Ireland Ltd. All rights reserved. Radiotherapy and Oncology 110 (2014) 482-487
The treatment of non-small cell lung cancer (NSCLC) stage T4N0-1 and stage IIIA-N2 with a single involved mediastinal nodal station is controversial. Although concurrent chemo-radiotherapy (CRT) is considered standard treatment for stage III NSCLC, some still advocate surgery combined with chemotherapy as the only treatment option capable of generating long-term survival in these subgroups with "potentially resectable", low-volume disease [1]. There are indeed many publications reporting surgical results for these subgroups, while prospective data on modern CRT are lacking [2-9]. To the best of our knowledge no data are available about the prognosis of a homogenous group of patients with single-station N2 or T4N0-1 NSCLC. Current radiotherapy series generally report on the whole group of mostly irresectable stage IIIA and IIIB NSCLC, but not on specific subgroups [10]. However, information

\footnotetext{
* Corresponding author.

E-mail address: bart.reymen@maastro.nl (B. Reymen).
}

about these particular subsets is crucial to enable a comparison of surgery to radiotherapy as local treatment. Even in the absence of phase III studies specifically designed for this purpose, knowledge of the potential outcome of patients with single-station N2 disease or T4N0-1 NSCLC can help clinicians to propose treatment choices to their patients.

\section{Patients and methods}

\section{Patient population}

We have previously reported on two prospective trials (NCT00573040 and NCT00572325) using individualised isotoxic accelerated radiotherapy (INDAR) with chemotherapy in NSCLC $[11,12]$. We now performed a subgroup analysis of these trials on patients staged T4N0-1 or IIIA-N2. All diagnostic images and pathology reports were checked to verify T4 status and if only one N2 station was involved. Patients included had an adequate 
lung function (FEV- 1 and DLCO $\geqslant 30 \%$ predicted), WHO-PS $\leqslant 2$ and $<10 \%$ weight loss over 6 months.

\section{Staging}

Staging was done following national guidelines with a whole body ${ }^{18}$ F-deoxyglucose (FDG)-Positron Emission Tomography (PET) scan, calibrated according to the NEDPAS protocol [13] and a contrast enhanced brain CT or MRI [5]. The diagnosis was pathologically confirmed in all patients. Each case was discussed by a multidisciplinary board including a pulmonologist, thoracic surgeon, pathologist, nuclear medicine physician, radiologist and a radiation oncologist.

T4 status was evaluated on imaging and defined according to the UICC TNM classification (fifth edition), excluding malignant pleural effusion. Patients considered fit for surgery underwent invasive mediastinal staging. Nodal involvement was pathologically confirmed whenever possible.

\section{Chemotherapy}

In our region stage III NSCLC was treated with sequential CRT up to 2005. In 2006 concurrent CRT was gradually introduced to become standard treatment from 2008 onwards. As previously described standard chemotherapy in sequential schedules was 3 courses of cisplatin $\left(75 \mathrm{mg} / \mathrm{m}^{2}\right.$ on day 1) combined with gemcitabine $\left(1250 \mathrm{mg} / \mathrm{m}^{2}\right.$ on days 1 and 8$)$. For concurrent CRT 1 cycle of carboplatin-gemcitabine (carboplatin AUC 5, gemcitabine $1250 \mathrm{mg} / \mathrm{m}^{2}$ ) was given before the onset of radiotherapy followed by 2 cycles of cisplatin-vinorelbine (cisplatin $40-50 \mathrm{mg} / \mathrm{m}^{2}$, vinorelbine $15-20 \mathrm{mg} / \mathrm{m}^{2}$ ) or cisplatin-etoposide (cisplatin 75$80 \mathrm{mg} / \mathrm{m}^{2}$ day 1 , etoposide $100 \mathrm{mg} / \mathrm{m}^{2}$ days $1-3$ ) concurrently with radiotherapy $[11,12]$. Standard dose reduction rules applied. Cisplatin was switched to carboplatin (area under the concentration-time curve $[A U C] 5$ ) in patients with renal impairment.

\section{Radiotherapy}

All patients received a contrast enhanced FDG PET-CT scan in treatment position (supine, arms raised) using a slice thickness of $3 \mathrm{~mm}$ for radiation treatment planning. Respiratory correlated CT (RCCT) images were also collected starting from April 2006.

Gross tumour volume (GTV-1) delineation was done on the RCCT images using appropriate window-level settings (lung: $W=1700, L=-300$, mediastinum: $W=600, L=40$ ), aided by FDG-PET. Involved hilar/mediastinal lymph nodes (GTV-2) were delineated on the RCCT in mediastinal setting. FDG-PET-negative nodes were not included in GTV-2 unless pathologically proven to be malignant. The CTV-margin was $5 \mathrm{~mm}$ for GTV-1 and GTV2 excluding vessels, bone and oesophagus. The CTV did not include elective nodal areas. PTV-margin was $5 \mathrm{~mm}$ for nodes and $10 \mathrm{~mm}$ for tumour. The healthy lung tissue (lungs-GTV), spinal cord and oesophagus were considered organs at risk. In patients treated with sequential chemotherapy, the post-chemotherapy tumour volume was defined as GTV and the included nodal areas were defined as staged pre-chemotherapy (PET-positive and/or pathology proven before start of chemotherapy).

Planning was performed on XIO (CMS, St. Louis) using a convolution-superposition algorithm for inhomogeneity correction. Standard radiotherapy consisted of INDAR up to a maximal total tumour dose (TTD) limited only by normal tissue dose constraints which was described in previous publications [11,12]. In short, 2 fractionation schedules were used. Concurrently with chemotherapy, the accelerated radiotherapy scheme was based on the ESPATÜ phase III trial scheme. It consisted of 30 fractions of $1.5 \mathrm{~Gy}$ twice daily (bid), followed by daily fractions of $2 \mathrm{~Gy}$ up to a maximal TTD limited by the normal tissue constraints between 51 and $69 \mathrm{~Gy}$. In this schedule a TTD of $65 \mathrm{~Gy}$ delivered in an OTT of 35 days matches a biological EQD2 corrected for time of $54 \mathrm{~Gy}$, corresponding to a dose of $72 \mathrm{~Gy}$ in $2 \mathrm{~Gy}$ fractions delivered in 50 days. This was calculated according to the linear quadratic model, corrected for overall treatment time:

$$
E Q D_{2, T}=D \bullet \frac{d+(\alpha / \beta)}{2+(\alpha / \beta)}-\left(T_{\text {ref }}-T\right) \bullet D_{\text {prolif }}
$$

We use an $\alpha / \beta$ ratio of $10 \mathrm{~Gy}$ for tumour, a $T_{\text {ref }}$ of 21 days and an assumed daily recovered dose in 2-Gy equivalent fractions after 21 days $\left(D_{\text {prolif }}\right.$ ) of $0.6 \mathrm{~Gy}[11,12,14]$. In sequential schedules we delivered $1.8 \mathrm{~Gy}$ fractions bid up to a TTD between 50.4 and $70.2 \mathrm{~Gy}$. In this schedule a TTD of $65 \mathrm{~Gy}$ delivered in an OTT of 25 days matches an EQD2 corrected for time of $61 \mathrm{~Gy}$. According to the same formula, this corresponds to a dose of $82 \mathrm{~Gy}$ in $2 \mathrm{~Gy}$ fractions. Normal tissue constraints were: maximal point dose $\left(D_{\max }\right)$ for spinal cord $=54 \pm 0.5 \mathrm{~Gy}$, mean lung dose (MLD) $19 \pm 1 \mathrm{~Gy}, D_{\max }$ for vessels $/$ bronchi $=74 \mathrm{~Gy}, D_{\max }$ for brachial plexus $=66$ Gy $[11,12]$. Treatment verification was performed using daily electronic portal imaging device measurements on each fraction, using set-up correction based on bony anatomy.

\section{Follow-up}

Patients were examined by the radiation oncologist 2-4 weeks after radiotherapy and followed until acute side-effects subsided to grade 1. Afterwards the pulmonologist followed patients three-monthly for the first year, six-monthly from years 2 to 5 and yearly thereafter. Chest CTs and X-rays were performed routinely. If progression was suspected a (PET-) CT was performed, complemented with biopsy if indicated. Toxicity was scored by clinicians at each visit (at baseline, during treatment and follow-up) according to CTC AE 3.0. The survival status of patients was updated in May 2013.

\section{Statistics}

Overall survival (OS) and progression-free survival (PFS) were calculated from pathological diagnosis using Kaplan-Meier statistics (SPSS version 17.0, IBM). Median survival rates are expressed together with their $95 \%$ confidence intervals $(\mathrm{CI})$, other results as mean \pm standard deviation and range. In this article follow-up is defined as follow-up of surviving patients.

\section{Results}

We identified 83 patients: 42 (34 male, 8 female) with T4N0-1 and 41 (24 male, 17 female) with single-station IIIA-N2 NSCLC. In 32 of 41 patients $(78 \%)$ with clinical single-station N2 disease, this was pathologically confirmed. In the remaining patients this was suspected on the PET-CT. Six out of 42 patients (14\%) had invasive confirmation (mediastinoscopy/thoracotomy) of T4 status. Patient characteristics are summarised in Tables $1 \mathrm{~A}$ and $1 \mathrm{~B}$.

At a median follow-up of 41 months local tumour failure occurred in 18 patients with T4N0-1 tumours (43\%). In 6 patients this remained the only disease site throughout follow-up. Regional nodal failure occurred in 5 patients (12\%), all of whom were previously staged T4NO and in all 5 patients simultaneous local tumour progression was present. Distant metastases occurred in 20 patients (47\%), involving brain metastases in 11 patients (26\%). Brain metastases were the first site of failure in 7 patients (17\%).

At a median follow-up of 39 months, local tumour failure occurred in 10 patients with stage IIIA-N2 disease (24\%) which was 
Table 1a

Patient and treatment characteristics T4.

\begin{tabular}{|c|c|c|}
\hline Characteristics & Median $/ n^{\circ} \pm S D$ & Range/(\%) \\
\hline Age & $62.5 \pm 9$ & $44-80$ \\
\hline $\begin{array}{l}\text { Gender } \\
\text { Male } \\
\text { Female }\end{array}$ & $\begin{array}{l}34 \\
8\end{array}$ & $\begin{array}{l}(81) \\
(19)\end{array}$ \\
\hline $\begin{array}{l}\text { WHO-PS } \\
0 \\
1 \\
2 \\
3\end{array}$ & $\begin{array}{l}17 \\
21 \\
3 \\
1\end{array}$ & $\begin{array}{l}(40) \\
(50) \\
(8) \\
(2)\end{array}$ \\
\hline $\begin{array}{l}\text { UICC TNM stage } \\
\text { cT4N0M0 } \\
\text { cT4N1M0 }\end{array}$ & $\begin{array}{l}36 \\
6\end{array}$ & $\begin{array}{l}(85) \\
(15)\end{array}$ \\
\hline $\begin{array}{l}\text { Class of T4 } \\
\text { Mediastinal invasion } \\
2 \text { Nodules in same lobe } \\
\text { Vertebral invasion } \\
\text { Mediastinal invasion }+2 \text { nodules same lobe }\end{array}$ & $\begin{array}{l}35 \\
1 \\
4 \\
2\end{array}$ & $\begin{array}{l}(83) \\
(2) \\
(10) \\
(5)\end{array}$ \\
\hline $\begin{array}{l}\text { Chemotherapy } \\
\text { Sequential } \\
\text { Concurrent }\end{array}$ & $\begin{array}{l}16 \\
26\end{array}$ & $\begin{array}{l}(38) \\
(62)\end{array}$ \\
\hline $\begin{array}{l}\text { GTV (in cc) } \\
\text { MLD (in Gy) } \\
\text { Prescribed TTD (in Gy) } \\
\text { Delivered TTD (in Gy) } \\
\text { OTT (in days) }\end{array}$ & $\begin{array}{l}80 \pm 109.5 \\
15 \pm 4.4 \\
65.0 \pm 7.3 \\
65.0 \pm 10 \\
30.5 \pm 7.5\end{array}$ & $\begin{array}{l}5.5-510 \\
5-19.9 \\
50.4-79.2 \\
21.6-79.2 \\
9-42\end{array}$ \\
\hline
\end{tabular}

Abbreviations: WHO-PS = World Health Organisation-Performance Status, GTV $=$ Gross Tumour Volume, UICC $=$ Union Internationale Contre Cancer, $\mathrm{TNM}=$ tumour, node, metastasis, $\mathrm{Gy}=\mathrm{Gray}, \mathrm{TTD}=$ total tumour dose, OTT $=$ overall treatment time.

Values in parentheses are percentages.

radically treated with re-irradiation in one patient. Regional nodal failure occurred in 7 patients (17\%). Four out of 7 patients relapsed outside the PTV. In all 7 patients, nodal failure either coincided with or was preceded by local or distant failure. Twenty-two patients (53\%) developed distant metastases during follow-up. In 18 patients (44\%) metastases were present at the initial time of diagnosis of progression. Ten patients (24\%) were diagnosed with brain metastases, being the first site of failure in 7 patients (17\%). Patterns of failure and actuarial loco-regional progression free survival for both groups are summarised in Table $2 \mathrm{~A}$ and $\mathrm{B}$ and Fig. 2.

In patients with T4N0-1 tumours the median actuarial OS was $34 \pm 7.5$ months (19.6-48.8 months) at a median follow-up of 48 months (65 months for sequential and 46 months for concurrent chemo-radiation with a 2 - and 3 -year survival of $55 \%$ and $44 \%$, respectively. Median actuarial PFS was $15 \pm 0.7$ months (9.7-20.2 months) with a 2- and 3-year PFS of 39\% and 34\%, respectively. The estimated 5 -year survival is $25 \%$. For patients treated with sequential CRT the median OS was $27 \pm 7$ months (13.340.7 months) compared with a median OS of $55 \pm 24$ months (7.9-102.1 months) for patients treated concurrently. Fig. 1 shows the overall survival curves for both groups.

The median follow-up of patients with stage IIIA-N2 disease was 50 months (70 months for sequential chemo-radiation and 41 months for concurrent chemo-radiation). The median actuarial OS for this group of patients was $26 \pm 5.3$ months (15.636.4 months) with a 2 - and 3 -year OS of $53 \%$ and $37 \%$, respectively. Five-year survival is estimated at $24 \%$. One patient was lost to follow-up and censored for progression 11 months after diagnosis. Median PFS was $24 \pm 7.4$ months (9.4-38.5 months) with a 2 - and 3 -year PFS of $51 \%$ and $31 \%$, respectively. For patients treated with sequential or concurrent CRT median OS was $26 \pm 6.7$ months
Table 1b

Patient and treatment characteristics IIIA-N2.

\begin{tabular}{|c|c|c|}
\hline Characteristic & Median $/ n^{\circ} \pm S D$ & Range/(\%) \\
\hline Age & $64 \pm 9$ & $44-78$ \\
\hline $\begin{array}{l}\text { Gender } \\
\text { Male } \\
\text { Female }\end{array}$ & $\begin{array}{l}24 \\
17\end{array}$ & $\begin{array}{l}(59) \\
(41)\end{array}$ \\
\hline $\begin{array}{l}\text { WHO-PS } \\
0 \\
1 \\
2\end{array}$ & $\begin{array}{l}17 \\
21 \\
3\end{array}$ & $\begin{array}{l}(41) \\
(51) \\
(7)\end{array}$ \\
\hline $\begin{array}{l}\text { UICC TNM stage } \\
\text { cT0N2M0 } \\
\text { cT1N2M0 } \\
\text { cT2N2M0 } \\
\text { cT3N2M0 }\end{array}$ & $\begin{array}{l}3 \\
12 \\
20 \\
6\end{array}$ & $\begin{array}{l}(7) \\
(29) \\
(49) \\
(15)\end{array}$ \\
\hline $\begin{array}{l}\text { Involved nodal station } \\
7 \\
4 \mathrm{R} \\
4 \mathrm{~L} \\
2 \mathrm{R} \\
5 \\
8\end{array}$ & $\begin{array}{l}20 \\
6 \\
1 \\
2 \\
11 \\
1\end{array}$ & $\begin{array}{l}(49) \\
(15) \\
(2) \\
(5) \\
(27) \\
(2)\end{array}$ \\
\hline $\begin{array}{l}\text { Chemotherapy } \\
\text { Sequential } \\
\text { Concurrent } \\
\text { GTV (in cc) } \\
\text { MLD (in Gy) } \\
\text { Prescribed TTD (in Gy) } \\
\text { Delivered TTD (in Gy) } \\
\text { OTT (in days) }\end{array}$ & $\begin{array}{l}15 \\
26 \\
44.21 \pm 90.5 \\
14.5 \pm 3.3 \\
65 \pm 6 \\
65 \pm 6.8 \\
30 \pm 6.7\end{array}$ & $\begin{array}{l}(37) \\
(63) \\
3.4-440 \\
7-21 \\
50.4-72 \\
43.5-72 \\
17-48\end{array}$ \\
\hline
\end{tabular}

Abbreviations: WHO-PS $=$ World Health Organisation-Performance Status GTV $=$ Gross Tumour Volume, UICC $=$ Union Internationale Contre Cancer, TNM = tumour, node, metastasis, Gy = Gray, TTD = total tumour dose, OTT = overal treatment time.

(13.3-38.6 months) and $23 \pm 9.3$ months (4.6-41.3 months) respectively.

In the group of $\mathrm{T} 4 \mathrm{~N} 0-1$ patients, 1 patient $(2 \%)$ experienced grade 3 dyspnoea caused by pulmonary embolism during radiotherapy, which subsided to grade 0 at 1 month after therapy. Interestingly, dyspnoea was present in $38 \%$ of patients before therapy, while 1 month after therapy this was only $16 \%$. One patient $(2 \%)$ developed grade 3 cough which resolved at 1 month after radiotherapy.

The most frequent severe side-effect was grade 3 esophagitis. This occurred in 7 patients (17\%) of whom 6 received concurrent CRT. In 5 patients tube feeding was initiated $(12 \%)$ which lasted for more than 1 month in 1 patient, namely until 6 weeks posttreatment. In the cohort of patients with stage IIIA-N2 disease 7 patients (17\%) developed grade 3 dysphagia during radiotherapy which required tube-feeding in 5 patients (12\%). One patient had grade 3 dysphagia until 8 weeks post-radiotherapy. All other patients had grade $0-1$ dysphagia at 1 month post-radiotherapy. One patient developed grade 4 dyspnoea due to cardiac failure during chemotherapy administration. One patient still suffered from grade 3 dyspnoea at 1 month after treatment due to pneumonia and cardiac arrhythmia complicated with pulmonary embolism. Four patients developed grade 3 cough. Two out of these 3 patients still presented with grade 2 cough at 1 month after radiotherapy. In all patients this complaint had resolved 2 months after treatment.

\section{Discussion}

Although standard treatment for most stage III NSCLC patients is concurrent chemo-radiotherapy, to the best of our knowledge 
Table 2

Patterns of relapse.

\begin{tabular}{lll}
\hline \multirow{2}{*}{ Recurrence } & \multicolumn{2}{l}{ Number of patients (\%) } \\
\cline { 2 - 3 } & $\mathrm{T} 4$ & IIIA-N2 \\
\hline No & $15(36)$ & $18(44)$ \\
Yes & $27(64)$ & $23(56)$ \\
Local tumour failure & $18(43)$ & $10(24)$ \\
Local failure + regional/distant failure & $12(29)$ & $8(19)$ \\
Isolated local tumour failure & $6(14)$ & $2(5)$ \\
Regional nodal failure & $5(12)$ & $7(17)$ \\
Nodal + local/distant failure & $5(12)$ & $7(17)$ \\
Isolated nodal failure (in field) & $0(0)$ & $0(0)$ \\
Distant failure & $20(48)$ & $22(54)$ \\
Distant + local/regional failure & $11(26)$ & $12(29)$ \\
Isolated distant failure & $9(21)$ & $10(24)$ \\
Isolated brain metastases & $5(12)$ & $3(7)$ \\
\hline
\end{tabular}

Location of relapses assessed with CT. Numbers between parentheses are percentages.

no data are available on the outcome of the N2 or T4N0-1 subgroups which are frequently considered surgical candidates. This perception is based on numerous surgical series reporting median survival of 20-43 months and 5-year survival rates from $24 \%$ up to $43 \%$ and an absence of radiotherapy data in these specific patients $[2,4-9,15,16]$.

This report reflects our current institutional policy through subgroup analysis of two prospective phase II trials. Since 2005 we use INDAR, delivering the highest dose of accelerated radiotherapy without exceeding normal tissue dose constraints, generating good survival results with acceptable toxicity $[11,12,17]$. Our median OS for T4N0-1 and single station IIIA-N2 of respectively 34 and 26 months and estimated 5-year survival of $25 \%$ and $24 \%$ compare well with surgical literature $[2,4,5,8,9,15,16]$, albeit having the advantage of PET-staging, which was not the case for most other studies. Our results in the IIIA-N2 cohort compare especially well with the two major randomised trials which have compared surgery to radiotherapy for stage IIIA-N2 NSCLC. EORTC 08941 randomised patients with unresectable stage IIIA-N2 NSCLC to surgery or radiotherapy after response to induction chemotherapy. Median survival in 165 patients treated with radiotherapy was 17.5 months and 5-year survival was $14 \%$ with a median PFS of 11.3 months [18]. In Intergroup 0139 patients with resectable stage IIIA-N2 were randomised between either definitive concurrent chemo-radiation to induction chemo-radiation followed by surgery. Seventy-five percent of patients in both groups had a single nodal station involved. Median survival after radiotherapy was 23.6 months with a median PFS of 12.8 months and a projected 5year survival of $20-25 \%$ [10]. Both trials found no significant difference in overall survival between surgery and radiotherapy.

Local tumour failure was more frequent in stage T4 (43\%) than in IIIA-N2 patients (22\%). A possible explanation is the median volume of the primary T4 tumours, which was twice that of the N2 patients, which is known to heavily impact tumour control in NSCLC $[19,20]$. This remains worrisome and needs improvement, possibly by further radiation dose escalation or selective combination with surgery or targeted agents [21]. Despite omission of elective nodal radiotherapy nodal recurrence rate was low.

Distant metastases are the predominant way of disease progression, occurring in about 50\% of patients, with brain metastases appearing in $25 \%$. This emphasises both the need for better systemic treatment and prevention of brain metastases.

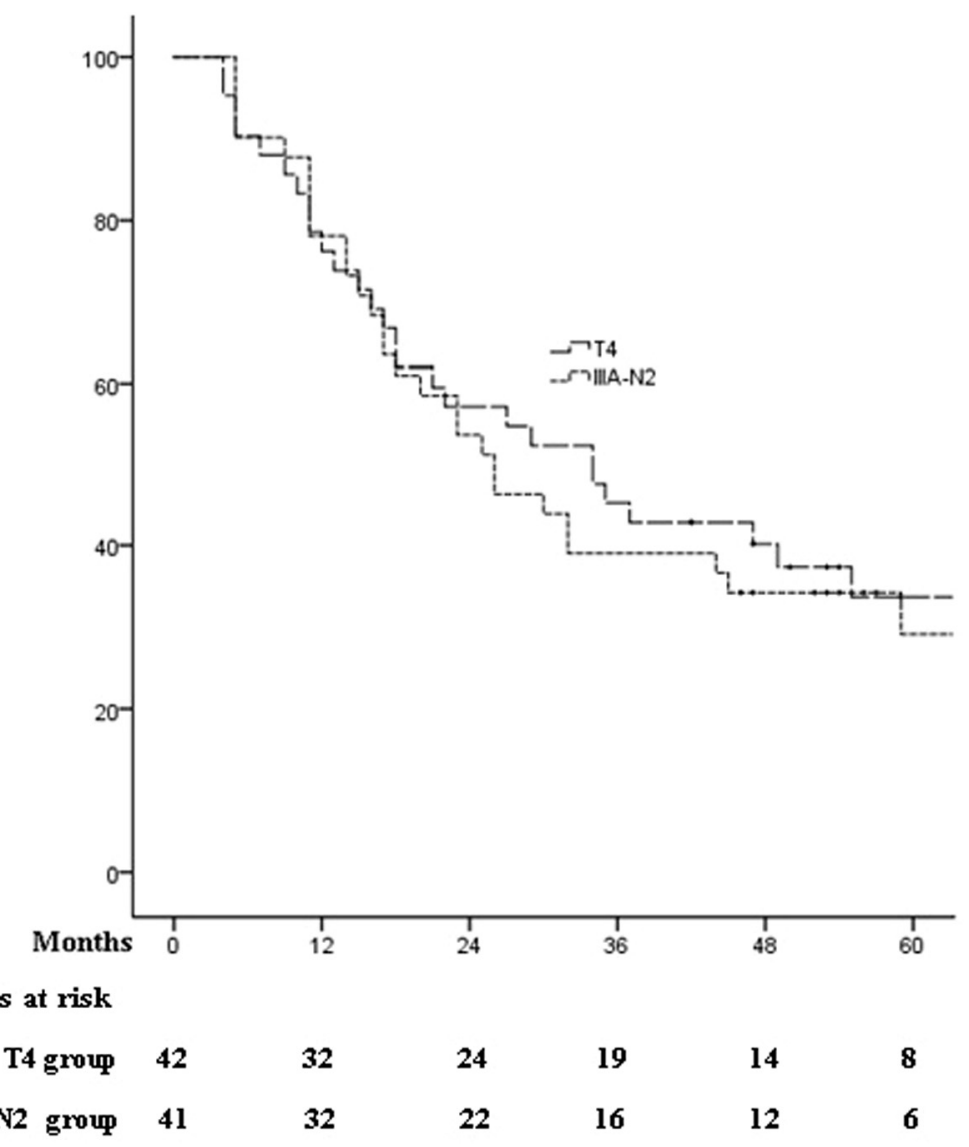

Fig. 1. Overall survival (Kaplan Meier). Actuarial overall survival of $42 \mathrm{~T} 4 \mathrm{~N} 0-1$ patients and 41 single nodal station stage IIIA-N2 patients. 


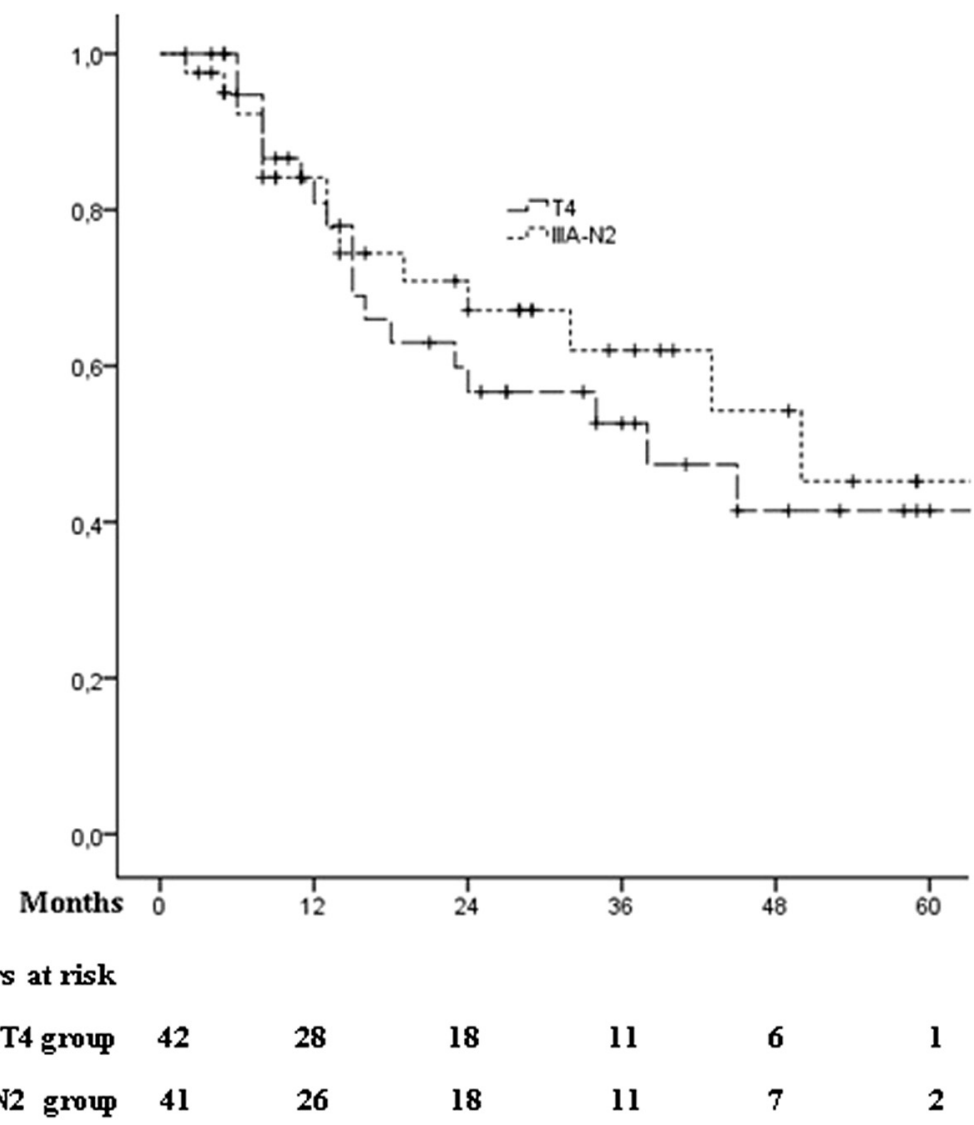

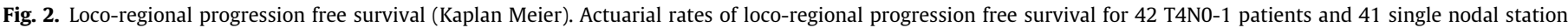
stage IIIA-N2 patients.

Toxicity was acceptable with grade 3 esophagitis occurring in $17 \%$ of patients, which is in line with literature on CRT for stage III NSCLC [10]. Treatment related mortality occurring within one month of treatment was low $(1 / 83,1 \%)$.

This study has some obvious shortcomings. First, T4 staging was mainly FDG-PET-CT based. Although contrast-enhanced PET-CT reportedly has a $>90 \%$ accuracy for defining $\mathrm{T}$ stage, some patients might ultimately have had pT3 and not pT4 tumours [22]. Second, we report on both concurrent and sequential chemo-radiotherapy, admitting the former to obviously being the standard treatment for fit patients with a stage III NSCLC. However, in worldwide clinical practice still a fairly large proportion of inoperable patients receive sequential CRT based on clinical judgment by treating physicians [23]. Third, although most stage IIIA-N2 patients had pathological validation of N2 status, invasive mediastinal staging (mediastinoscopy) was not routinely performed, which may have led to nodal understaging. A final comment is that the tumour with 2 nodules in the same lobe which was classified as T4 would be considered T3 in the current (seventh) TNM staging system. We have kept this patient in the analysis to allow comparison with most other articles on surgery or radiotherapy for T4 NSCLC which have also made use of the TNM fifth or sixth edition.

Keeping all caveats in mind, this study shows that accelerated, individualised CRT is a valuable treatment option for T4N0-1M0 and single-station IIIA-N2 NSCLC, achieving long-term survival in about $25 \%$ of patients with low morbidity. However, since $25 \%$ long-term survival and high rates of loco-regional and distant relapse obviously remain unsatisfactory, research opportunities in this specific patient population include the investigation of higher, individualised radiation doses delivered with appropriate conformal techniques to minimise toxicity, improvement in the combination with chemotherapy and possibly even biologically targeted agents as well as consideration of surgery in selected patients $[21,24-26]$.

\section{Conflict of interest notification}

None declared.

\section{References}

[1] Ramnath N, Dilling TJ, Harris LJ, et al. Treatment of stage III non-small cell lung cancer: diagnosis and management of lung cancer, 3rd ed.: American College of Chest Physicians evidence-based clinical practice guidelines. Chest 2013:143:e314S-340S.

[2] Betticher DC, Hsu Schmitz SF, Totsch M, et al. Mediastinal lymph node clearance after docetaxel-cisplatin neoadjuvant chemotherapy is prognostic of survival in patients with stage IIIA pN2 non-small-cell lung cancer: a multicenter phase II trial. J Clin Oncol 2003;21:1752-9.

[3] Farjah F, Wood DE, Varghese Jr TK, et al. Trends in the operative management and outcomes of T4 lung cancer. Ann Thorac Surg 2008;86:368-74.

[4] Lorent N, De Leyn P, Lievens $Y$, et al. Long-term survival of surgically staged IIIA-N2 non-small-cell lung cancer treated with surgical combined modality approach: analysis of a 7-year prospective experience. Ann Oncol 2004;15:1645-53.

[5] Ma Q, Liu D, Guo Y, et al. Surgical therapeutic strategy for non-small cell lung cancer with mediastinal lymph node metastasis (N2). Zhongguo Fei Ai Za Zhi 2010;13:342-8.

[6] Chambers A, Routledge T, Bille A, et al. Does surgery have a role in T4N0 and T4N1 lung cancer? Interact Cardiovasc Thorac Surg 2010;11:473-9.

[7] De Leyn P, Vansteenkiste J, Lievens Y, et al. Survival after trimodality treatment for superior sulcus and central T4 non-small cell lung cancer. J Thorac Oncol 2009;4:62-8.

[8] Kunitoh H, Kato H, Tsuboi $M$, et al. Phase II trial of preoperative chemoradiotherapy followed by surgical resection in patients with superior 
sulcus non-small-cell lung cancers: report of Japan Clinical Oncology Group trial 9806. J Clin Oncol 2008;26:644-9.

[9] Pitz CC, Brutel de la Riviere A, van Swieten HA, et al. Results of surgical treatment of T4 non-small cell lung cancer. Eur J Cardiothorac Surg 2003;24:1013-8.

[10] Albain KS, Swann RS, Rusch VW, et al. Radiotherapy plus chemotherapy with or without surgical resection for stage III non-small-cell lung cancer: a phase III randomised controlled trial. Lancet 2009;374:379-86.

[11] van Baardwijk A, Reymen B, Wanders S, et al. Mature results of a phase II trial on individualised accelerated radiotherapy based on normal tissue constraints in concurrent chemo-radiation for stage III non-small cell lung cancer. Eur J Cancer 2012;48:2339-46.

[12] van Baardwijk A, Wanders S, Boersma L, et al. Mature results of an individualized radiation dose prescription study based on normal tissue constraints in stages I to III non-small-cell lung cancer. J Clin Oncol 2010;28:1380-6.

[13] Boellaard R, Oyen WJ, Hoekstra CJ, et al. The Netherlands protocol for standardisation and quantification of FDG whole body PET studies in multicentre trials. Eur J Nucl Med Mol Imaging 2008;35:2320-33.

[14] van Baardwijk A, Bosmans G, Bentzen SM, et al. Radiation dose prescription for non-small-cell lung cancer according to normal tissue dose constraints: an in silico clinical trial. Int J Radiat Oncol Biol Phys 2008;71:1103-10.

[15] Rendina EA, Venuta F, De Giacomo T, et al. Induction chemotherapy for T4 centrally located non-small cell lung cancer. J Thorac Cardiovasc Surg 1999; 117:225-33.

[16] Rusch VW, Giroux DJ, Kraut MJ, et al. Induction chemoradiation and surgical resection for superior sulcus non-small-cell lung carcinomas: long-term results of Southwest Oncology Group Trial 9416 (Intergroup Trial 0160). J Clin Oncol 2007;25:313-8.

[17] De Ruysscher D, Belderbos J, Reymen B, et al. State of the art radiation therapy for lung cancer 2012: a glimpse of the future. Clin Lung Cancer 2013;14:89-95.
[18] van Meerbeeck JP, Kramer GW, Van Schil PE, et al. Randomized controlled trial of resection versus radiotherapy after induction chemotherapy in stage IIIA-N2 non-small-cell lung cancer. J Natl Cancer Inst 2007;99:442-50.

[19] Dehing-Oberije C, Yu S, De Ruysscher D, et al. Development and external validation of prognostic model for 2-year survival of non-small-cell lung cancer patients treated with chemoradiotherapy. Int J Radiat Oncol Biol Phys 2009;74:355-62.

[20] Soliman M, Yaromina A, Appold S, et al. GTV differentially impacts locoregional control of non-small cell lung cancer (NSCLC) after different fractionation schedules: subgroup analysis of the prospective randomized CHARTWEL trial. Radiother Oncol 2013;106:299-304.

[21] Koh PK, Faivre-Finn C, Blackhall FH, et al. Targeted agents in non-small cell lung cancer (NSCLC): clinical developments and rationale for the combination with thoracic radiotherapy. Cancer Treat Rev 2012;38:626-40.

[22] Pfannenberg AC, Aschoff P, Brechtel K, et al. Low dose non-enhanced CT versus standard dose contrast-enhanced CT in combined PET/CT protocols for staging and therapy planning in non-small cell lung cancer. Eur J Nucl Med Mol Imaging 2007;34:36-44.

[23] De Ruysscher D, Botterweck A, Dirx M, et al, Eligibility for concurrent chemotherapy and radiotherapy of locally advanced lung cancer patients: a prospective, population-based study. Ann Oncol 2009;20:98-102.

[24] Partridge M, Ramos M, Sardaro A, et al. Dose escalation for non-small cell lung cancer: analysis and modelling of published literature. Radiother Oncol 2011;99:6-11.

[25] Kappers I, Klomp HM, Koolen MG, et al. Concurrent high-dose radiotherapy with low-dose chemotherapy in patients with non-small cell lung cancer of the superior sulcus. Radiother Oncol 2011;101:278-83.

[26] Shen WY, Ji J, Zuo YS, et al. Comparison of efficacy for postoperative chemotherapy and concurrent radiochemotherapy in patients with IIIA-pN2 non-small cell lung cancer: an early closed randomized controlled trial. Radiother Oncol 2013;110:120-5. 